\title{
BEAM MODELING FOR PGNAA EXPERIMENTAL FACILITY AT KARTINI REACTOR
}

\section{PEMODELAN BERKAS UNTUK FASILITAS PGNAA PADA REAKTOR KARTINI}

\author{
Tegas Sutondo \\ Center for Accellerator Science and Technology (CAST), BATAN \\ Jl. Babarsari, P.O. Box 6101 ykbb, Yogyakarta 55281 \\ e-mail: tegas@batan.go.id; tegas_s@yahoo.com
}

Received 25 May 2016, received in revised form 17 July 2015, accepted 30 July 2015

\begin{abstract}
BEAM MODELING FOR PGNAA EXPERIMENTAL FACILITY AT KARTINI REACTOR. A feasibility study on possible use of Kartini reactor's beam port for Prompt Gamma Neutron Activation Analysis (PGNAA) experimental facility is going on. This work is part of the revitalization program activities of Kartini research reactor, including utilization of the available irradiation facilities. This paper presents results of beam modeling at the tangential beam port to get neutron beam meeting the specified criteria. The study was conducted by means of simulations using MCNPX code. The result concludes that there are several possible variations of collimator models that can provide neutron beam meeting the specified criteria and that tangential beam port is considered to be feasible enough for the purpose of PGNAA experimental facility
\end{abstract}

Keywords: beam, modeling, PGNAA, facility, Kartini reactor.

\section{ABSTRAK}

PEMODELAN BERKAS UNTUK FASILITAS PGNAA PADA REAKTOR KARTINI. Pada saat ini sedang dilakukan studi kelayakan terkait kemungkinan penggunaan beam port dari reaktor Kartini untuk sarana eksperimen Prompt Gamma Neutron Activation Analysis (PGNAA). Kegiatan ini bagian dari program revitalisasi dari reaktor Kartini, termasuk pemanfaatan fasilitas irradiasi yang ada. Makalah ini menyajikan hasil dari pemodelan berkas pada beam port singgung untuk mendapatkan berkas neutron sesuai dengan persyaratan yang ditetapkan. Studi ini dilakukan berdasarkan dengan cara simulasi menggunakan program PCNPX. Dari hasil simulasi dapat disimpulkan bahwa ada beberapa variasi model kolimator yang dapat menghasilan berkas neutron sesuai kriteria yang ditetapkan, dan beam port singgung cukup layak untuk digunakan sebagai fasilitas eksperimen PGNAA.

Kata kunci: pemodelan, berkas, fasilitas. PGNAA, reaktor Kartini.

\section{INTRODUCTION}

artini reactor is a pool type TRIGA mark II reactor, operated with nominal power of $100 \mathrm{~kW}$, and equipped with several irradiation facilities, including 4 beam ports that can be used for many different applications, as shown in Figure 1.
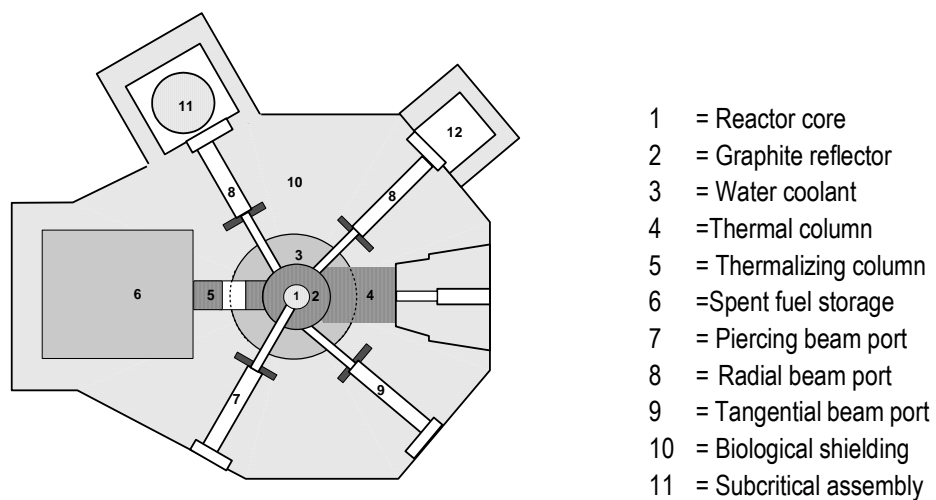

Figure 1. Horizontal cut view of Kartini Reactor. 
Among the irradiation facilities available, Lazy Susan is being the most frequently used for elemental analysis, based on the Neutron Activation Analysis (NAA) techniques, which is known as DGNAA (Delayed Gamma Neutron Activation Analysis).

In conjunction with the revitalization program of Kartini reactor, there is interest to build a PGNAA experimental facility by utilizing one of the beam ports which are still not utilized optimally, i.e. radial piercing, radial and tangential beam ports. PGNAA is another variant of NAA techniques, working based on the gamma rays emitted promptly following the decay of the compound nucleus (CN) formed in the excited state. The intensity of the gamma-rays emitted is directly proportional to isotopic (elemental) concentrations. This technique has enabled the in situ and on-line application such as those used in coal mining; cement industries, etc. (1-4).

PGNAA technique, basically can work with the whole range of neutron energy spectrum, depending on the neutronic properties of the sample to be analyzed. However for most research application it is preferred to use neutrons of lower energy range, since activation reactions occur mostly with neutrons of low energies. An exception is for nuclides having very low thermal neutron capture reaction such as carbon, it is preferred to use fast neutron, throughout the neutron inelastic scattering reaction (2).

For PGNAA working with thermal neutron, the contribution of epithermal activation reactions, may affect the accuracy of the result, and therefore it should be minimized as much as possible to a reasonable level. This commonly indicated with the amount of thermal over epithermal neutron fluxes ratio ( $f$ ), implying that the higher the value of $f$ will be the better the quality of the neutron beam accordingly. A minimum $f$ value of 100 was considered to be reasonable, with minimum thermal neutron flux $=1.0 \times 10^{6} \mathrm{n} \mathrm{cm}^{-2} \mathrm{~s}^{-1}(5)$. In this respect, attempt will be made to get neutron beam meeting the above criteria.

A preliminary study has been carried out by characterizing the three kinds of beam port to select the most suitable one which is going to be used; i.e. the radial piercing and tangential beam port (6) and then also to include the radial beam port which was previously used for neutron radiography experimental facility. The study was performed by means of simulation using MCNPX code. Figure 2 summaries results of simulation of the neutron beam at the beam ports exit and Figure 3 is the corresponding radiation dose of both neutron and photon radiation.

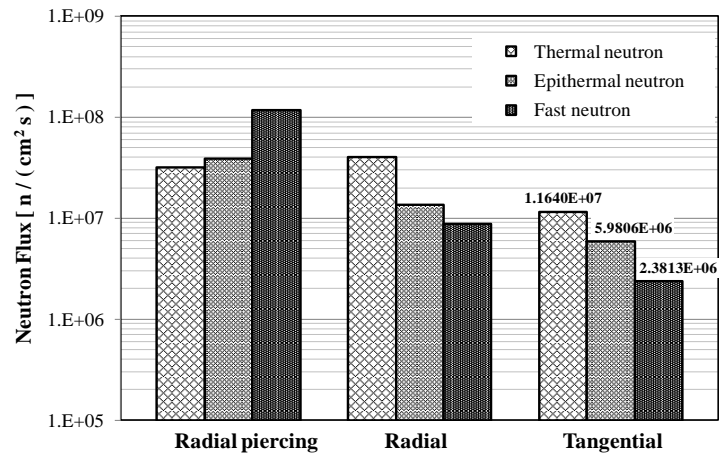

Figure 2. Beam characteristics at the beam port exit.

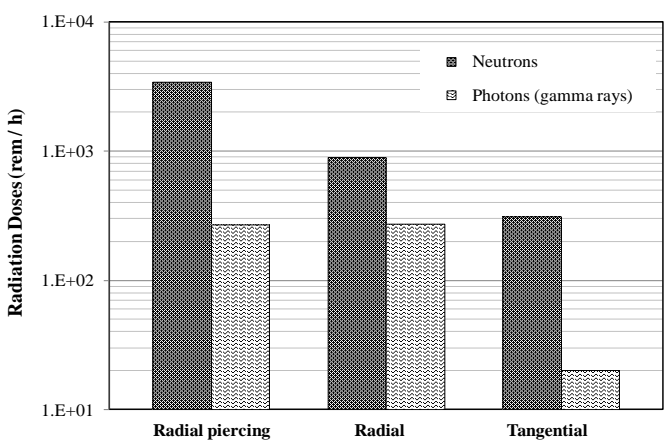

Figure 3. The radiation dose at the beam port exit

The result shows that the radial piercing beam port provides the highest value of neutron fluxes. The photon radiation dose is also very high which is comparable with that of radial beam port. The high intensity of both fast neutrons and photons would need more works to do for both moderating the fast neutrons and suppressing the gamma rays as well. Radial beam port seen to give highest thermal neutron compared with the others, however the gamma rays radiation dose is of the same order with that of radial piercing beam port.

Finally the tangential beam port provides much lower fast neutron and gamma rays radiation dose. This can help simplify the problems of both moderating the fast neutron and suppressing the gamma rays. Based on the above results, it was then decided to use tangential beam port as the object of collimator modeling in this work. Figure 4 depicts the tangential beam port, consisting two sections i.e. inner section made of aluminum and outer section made of steel both with thickness of $0.95 \mathrm{~cm}$. 


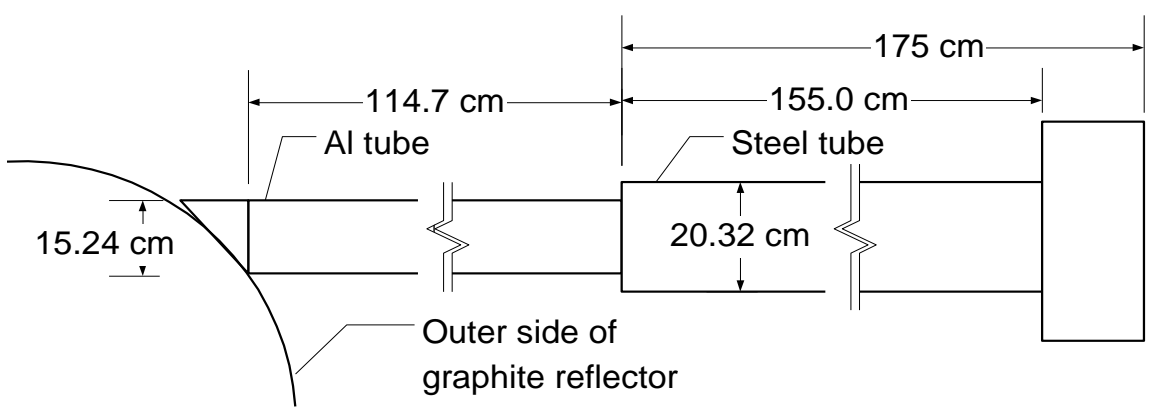

Figure 4. Inner and outer sections of tangential beam port.

\section{METHODOLOGY}

There are many different models of collimator having been developed, for several different applications (7-11). In this study, a basic geometrical model of collimator as represented in Figure 5 was used. The collimator consists of three main sections i.e. inner, middle and outer sections each with the length of $L-1, L-2$, and $L-3$ respectively.

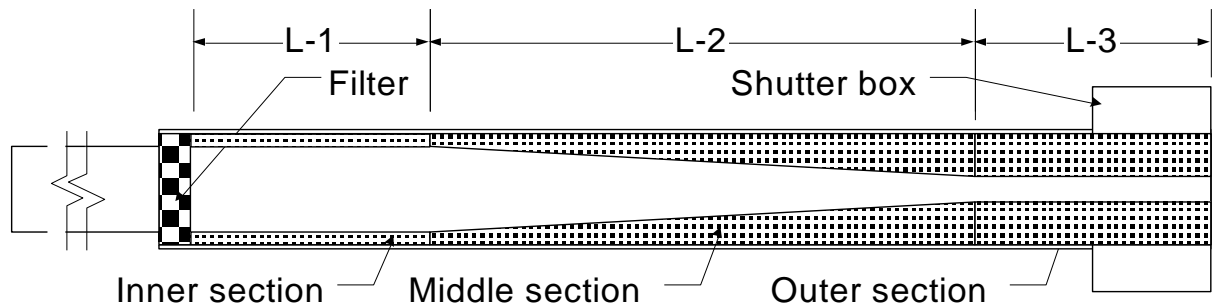

Figure 5. Basic shape of the collimator model.

The goal of this work is to suppress the gamma rays component to a reasonable level that can help simplify the problem of shielding and to get neutron beam meeting the defined criteria. This will be performed by means of selecting the suitable materials and adjusting the dimensions of each collimator section. For this purpose, it will be prioritized to use materials available in local market and relatively inexpensive.

Lead $(\mathrm{Pb})$, with density of $11.34 \mathrm{~g} / \mathrm{cm}^{3}$ is good for suppressing gamma rays, and it has also low neutron capture cross section which is relatively transparent against neutron passage ${ }^{(12,13)}$. In this respect, it will be used for the main component of collimator wall.

Another material having similar properties with lead is bismuth (Bi) with density of $9.780 \mathrm{~g} / \mathrm{cm}^{3}$. It has low neutron capture cross section and high neutron elastic cross section that can improve the neutron transmission. In this respect, it will be included as part of evaluation for material of filter, inner and or outer sections wall.

Polyethylene of high density (HDPE) with density of $0.95 \mathrm{~g} / \mathrm{cm}^{3}$ has low neutron capture cross section and high elastic scattering cross section which could improve the moderation of fast neutrons. It was also included in the evaluation for material of inner and outer section wall to help increase the thermal neutron production.

All of the above materials are easily obtained in local market and relatively inexpensive. Figure 6,7 , and 8 shows the MCNPX plot of neutron capture cross sections of lead, bismuth and HDPE respectively and Fig. 9, 10, 11 are the corresponding elastic scattering cross sections.

The MCNP geometrical representation was prepared and a Visual Editor - VISED Version X_22S ${ }^{(15)}$ was used for visual reviewing of the geometrical model. Simulations were performed for several different models which include the variation of materials for both the filter and collimator wall of inner and outer sections, and the corresponding dimensions. In this study, the criticality source (KCODE) option was used to calculate neutrons and photons fluxes, normalized to reactor power of $100 \mathrm{~kW}$. 


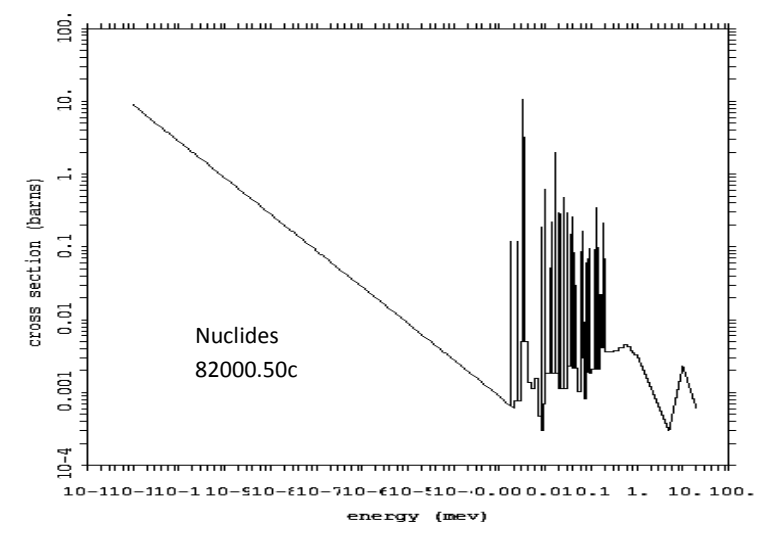

Figure 6. Neutron capture cross section of lead.

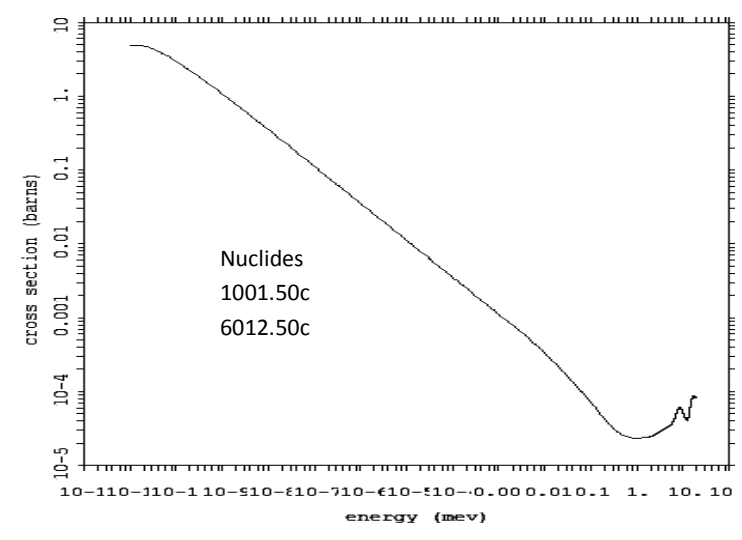

Figure 8. Neutron capture cross section of HDPE.

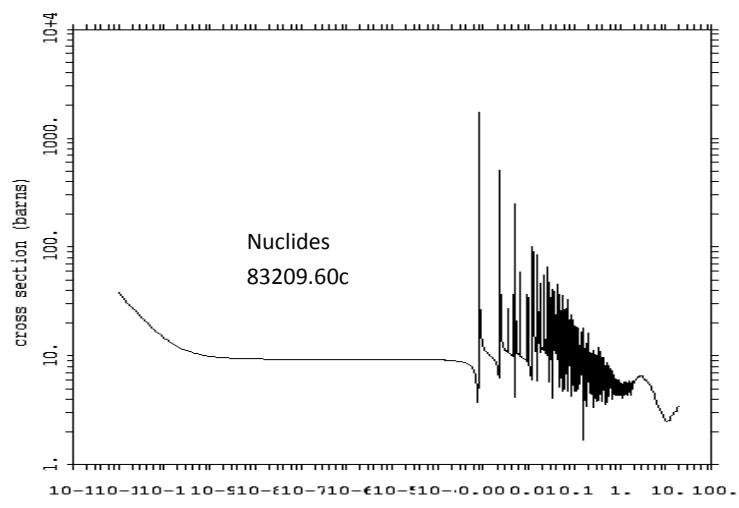

energy (mev)

Figure 10. Neutron Elastic cross section of bismuth.

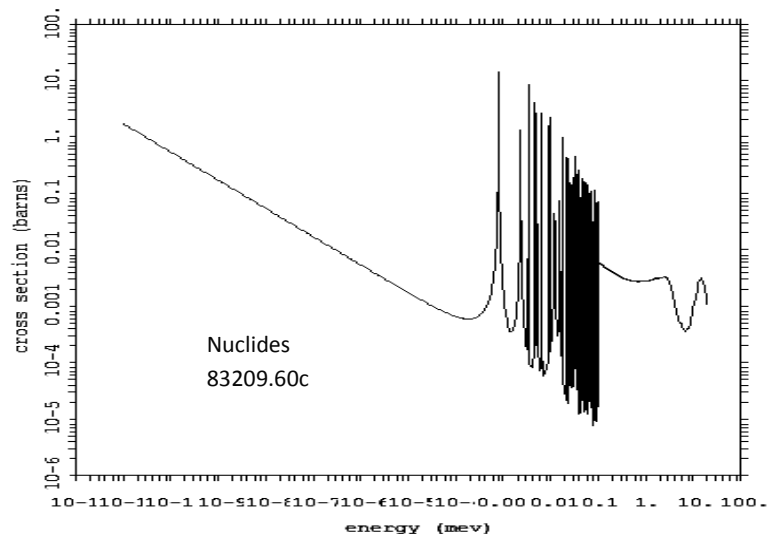

Figure 7. Neutron capture cross section of bismuth.

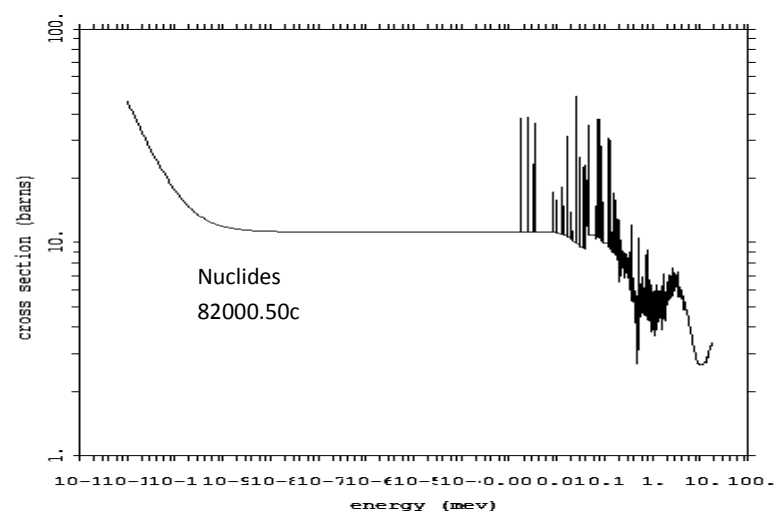

Figure 9. Neutron elastic cross section of lead.

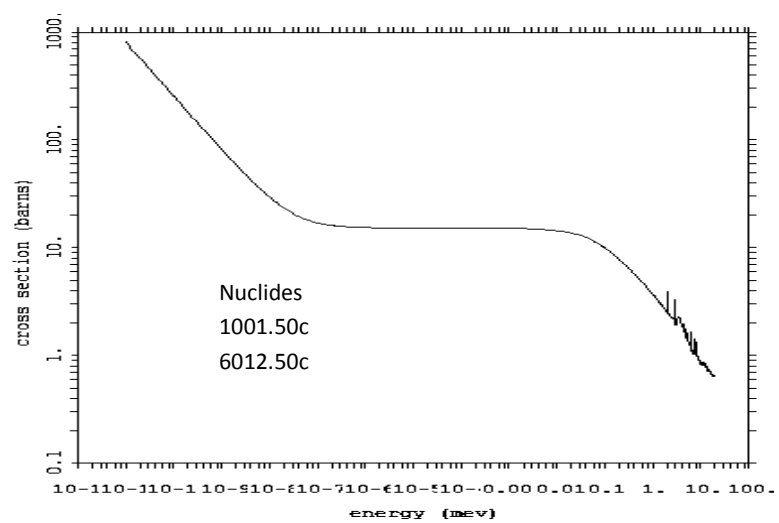

Figure 11. Neutron elastic cross section of HDPE. 


\section{RESULTS AND DISCUSSIONS}

Several cases of simulation had been exercised based on the basic collimator model as represented by Figure 5 . Figure 12 shows a piece of MCNP geometrical representation of a collimator model placed at the outer section of the tangential beam port.

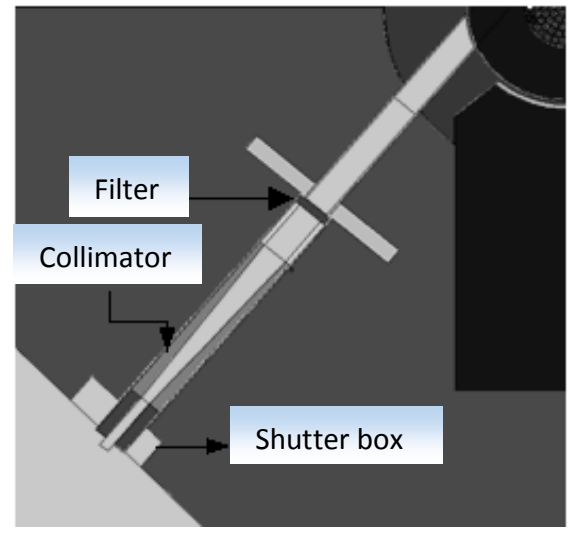

Figure 12. Piece of the MCNP representation of collimator model.

Table 1 presents results of several cases of simulation using filter material of either lead or bismuth, with the same thickness of $5.0 \mathrm{~cm}$, which can provide neutron beam at the exit, meeting the minimum defined criteria.

In case-1, the filter and the wall of collimator sections all use material of lead. Based on the prescribed collimator dimensions the photons and the epithermal and fast neutrons can be removed from the beam at the exit. The thermal flux obtained is still higher than the defined minimum value of $1.0 \times 10^{6} \mathrm{n} \mathrm{cm}^{-2} \mathrm{~s}^{-1}(5)$.

In case-2, the filter material was replaced by bismuth (Bi) and the length of inner section (L-1) was extended by $10 \mathrm{~cm}$, (which result in the reduction of L-2 by $10 \mathrm{~cm}$ ). This way could result in the increase of thermal neutron flux, but then with the presence of fast neutrons component. The presence of fast neutron theoretically would not give a significant contribution to the accuracy of the PGNAA since the activation cross section is much lower than that of thermal neutron. However, if most of fast neutron energies close to the upper limit of epithermal energy, it could affect the accuracy of the result.

In case-3, simulation was made by replacing the material of inner section wall with bismuth and outer section wall with HDPE, whilst keeping the dimensions unchanged. This way could remove the fast neutron component, but with a bit appearance of gamma rays which can then be removed by slightly reducing the outer radius of aperture as seen in case-4. The thermal neutron beam obtained represents the average value of several repeated simulation results, with relative differences of around $13 \%$. However more repetitions of the simulations might still be needed to get the best representing result. This value seen to be much higher compared with that obtained in case- 1 which used lead for both filter and all sections of the collimator wall.

Table 1. Result of simulations.

\begin{tabular}{ccccc}
\hline Cases of Simulation & Case - 1 & Case - 2 & Case - 3 & Case - 4 \\
\hline Filter Thickness $(\mathrm{cm})$ & 5.0 & 5.0 & 5.0 & 5.0 \\
\hline Filter & & Material & & \\
\hline Inner section & Lead & Bismuth & Bismuth & Bismuth \\
\hline Middle section & Lead & Lead & Bismuth & Bismuth \\
\hline Outer section & Lead & Lead & Lead & Lead \\
\hline & Lead & Lead & HDPE & HDPE \\
\hline
\end{tabular}




\begin{tabular}{|c|c|c|c|c|c|}
\hline \multicolumn{2}{|c|}{ Cases of Simulation } & Case - 1 & Case - 2 & Case - 3 & Case - 4 \\
\hline \multicolumn{6}{|c|}{ Length $(\mathrm{L}-1, \mathrm{~L}-2, \mathrm{~L}-3)$ / radius of base / radius of top $(\mathrm{cm})$} \\
\hline \multicolumn{2}{|c|}{ Inner section } & $20 / 7.5 / 7.5$ & $30 / 7.5 / 7.5$ & $30 / 7.5 / 7.5$ & $30 / 7.5 / 7.5$ \\
\hline \multicolumn{2}{|c|}{ Middle section } & $130 / 7.5 / 3.0$ & $120 / 7.5 / 3.0$ & $120 / 7.5 / 3.0$ & $120 / 7.5 / 2.5$ \\
\hline \multicolumn{2}{|c|}{ Outer section } & $20 / 3.0 / 3.0$ & $20 / 3.0 / 3.0$ & $20 / 3.0 / 3.0$ & $20 / 2.5 / 2.5$ \\
\hline \multirow{3}{*}{$\begin{array}{l}\text { Neutron flux } \\
\text { at the exit } \\
\left(\mathrm{n} \mathrm{cm}^{-2} \mathrm{~s}^{-1}\right)\end{array}$} & Thermal & $6.54690 \times 10^{6}$ & $1.60123 \times 10^{7}$ & $1.70924 \times 10^{7}$ & $1.4269 \times 10^{7}$ \\
\hline & Epithermal & - & - & - & - \\
\hline & Fast & - & $3.49839 \times 10^{6}$ & - & - \\
\hline \multicolumn{2}{|c|}{$\begin{array}{c}\text { Total photon flux } \\
\text { at beam exit }\left[\gamma \mathrm{cm}^{-2} \mathrm{~s}^{-1}\right]\end{array}$} & - & - & $4.01497 \times 10^{6}$ & - \\
\hline
\end{tabular}

\section{CONCLUSION}

A series of simulation cases of beam modeling have been carried out as part of feasibility study on using Kartini reactor's beam port for PGNAA experimental facility. Tangential beam port has been selected for the purpose of this study. The study was conducted by means of simulation using MCNPX code. Results of simulation indicate that there are several possible variations of collimator models that can provide neutron beam meeting the specified criteria. Based on the simulation results, it is concluded that the tangential beam port is feasible enough for the proposed of PGNAA application with the neutron beam at the beam port exit meets the specified criteria.

\section{ACKNOWLEDGMENT}

The author would like to thank to Director of CAST-BATAN Yogyakarta, Prof. Sudjatmoko, Prof. Syarip, the manager and the project coordinator for their great supports.

\section{REFERENCES}

1. DARIUSH REZAI, MOHAMMAD MOHAMMADI, Prompt Gamma Neutron Activation Analysis of Carbon Bulk Samples with an Am-Be Neutron Source, JTPC, Vol. 1 (2012) 11-13

2. TAREK Q. QASIM, TAWFEQ AL-ETAIWI, MOHAMMED AL-KHASHEB, "Analysis and Developments of PGNAA Installation at Al-Rashadiya Lafarge Cement Plant in Jordan", Proceedings of the 2011 International Conference on Industrial Engineering and Operations Management, Kuala Lumpur, Malaysia, January 22 - 24, (2011) 1219-1224

3. DARRELL LEETHAM, PGNAA Improves Process and Quality Control in Cement Production, Accelerating Science, (2014)

4. AKHTAR ABBAS NAQVI, et al, Prompt Gamma-Ray Analysis of Steel Slag in Concrete, Journal of Nuclear Science and Technology, 46:7, Published online: 19 Mar (2012) 737-743

5. ALEXANDRE SOARES LEAL", DANIEL CAMPOLINA, ZSOLTREVAY, "Feasibility Of The Prompt-Gamma Neutron Activation Analysis Facility At Trigaipr-R1 Reactor In Brazil", International conference on research reactor safe management and effective utilization, Proceeding IAEA-CN-188-A19, Rabat Morocco 14-18 November (2011) 1-8

6. TEGAS SUTONDO and SYARIP, Karakteristik Berkas Pada Beam Port Tembus dan Singgung Reaktor Kartini, "Ganendra" Journal of Nuclear Science and Technology, Vol. 17 No. 2 (2014) 83-90

7. M.R. A ABDI, K.H. REZAEE, P. SHAYAN AND A. FARZANEH, Collimator Design for Neutron Radiography Systems Using a Reactor Flux, Middle-East Journal of Scientific Research 11 (5): (2012) 648-651 
8. YANG XIAO-PENG, et al. Neutron collimator design of neutron radiography based on the BNCT facility, Chinese Physics C, Vol. 33, No 1, (2013) 010201, 1-5

9. J. G. FANTIDIS, et al, A transportable neutron radiography system, J Radioanal Nucl Chem 284 (2010): 479-484

10. FATEMEH SADAT RASOULI, SEYED FARHAD MASOUDI, Simulation of the BNCT of Brain Tumors Using MCNP Code: Beam Designing and Dose Evaluation, Iranian Journal of Medical Physics Vol. 9, No. 3 (2012) 183-192

11. VICTOR KREFT, Studies Towards Boron Neutron Capture Synovectomy At Mcmaster University, A Thesis Submitted to the School of Graduate Studies in Partial Fulfillment of the Requirements for the Degree Doctor of Philosophy, McMaster University, Hamilton, Ontario (2014). https://macsphere.mcmaster.ca/handle/11375/ 16157, down loaded on February 6, (2015)

12. N. SHMELEV, G. G. KULIKOV, V. A. APSE, E. G. KULIKOV, AND V. V. ARTISYUK, Radiogenic Lead with Dominant Content of 208Pb: New Coolant and Neutron Moderator for Innovative Nuclear Facilities, Hindawi Publishing Corporation, Science and Technology of Nuclear Installations Volume (2011) 1-12

13. Liquid Metal Coolants For Fast Reactors Cooled By Sodium, Lead, And Lead-Bismuth Eutectic, IAEA Nuclear Energy Series No. Np-T-1.6.

14. A.L. SCHWARZ, R.A. SCHWARZ, AND L.L. CARTER, MCNP/MCNPX Visual Editor (VISED) Computer Code Manual, RSICC id: C00746MNYCP00, February, (2008) 